\title{
Atlardan İzole Edilen Streptococcus equi Suşlarının Moleküler İdentifikasyonu ve Antibiyotik Duyarlılıklarının Saptanması
}

\author{
Abdullah Burak ÇALIŞKAN ${ }^{1, a}$, Osman Yaşar TEL ${ }^{2, b, *}$ \\ ${ }^{1}$ TJK Şanlıurfa Hipodrom Müdürlüğü, ŞANLIURFA \\ ${ }^{2}$ Harran Üniversitesi Veteriner Fakültesi Mikrobiyoloji Anabilim Dalı, ŞANLIURFA \\ aORCID: 0000-0001-5367-5480, bORCID: 0000-0001-7848-3899
}

Geliş Tarihi: 20.07.2020

Kabul Tarihi: 18.01.2021

\begin{abstract}
Özet: Su sakağısı, atlarda Streptococcus equi subsp. equi (S. equi )'nin neden olduğu akut seyirli, bulaşıCı ve irinli lenfadenitisle karakterize bir hastalıktır. Hastalık genellikle taylarda görülür ve hastalıkta üst solunum yolu ile ilgili bölgesel lenf nodüllerinde veya ender olarak da generalize formda apseleşme görülür. Hastalık tüm yaşlardaki tek tırnaklıları etkiler. Bu çalışmada atlardan S. equi izolasyonu ve izolatların PCR ile moleküler olarak identifikasyonu ve antibiyotik duyarlılık profillerinin saptanması amaçlandı. Bu amaçla materyal olarak 60 attan alınan burun svabı ve tracheal yıkantı sıvısı örnekleri kullanıldı. Örneklerin kolistin ve nalidiksit asit içeren kanlı agara ekimleri yapılarak, $\% 5 \mathrm{CO}_{2}^{\prime}$ li ortamda $37{ }^{\circ} \mathrm{C}$ inkubasyona bırakıldı. Örneklerin kültür yoluyla incelenmesi sonucunda 22'sinden (\%36) Streptococcus spp. izolasyonu gerçekleştirildi. İzole edilen 22 suşun, 3’ü $(\% 19,1)$ S. equi, 19’u $(\% 20,6)$ Streptococcus zooepidemicus (S. zooepidemicus) olarak identifıye edildi. İzolatların superoxide dismutase-sodA gen bölgesinin amplifikasyonu sonucunda 3 S. equi ve 19 S. zooepidemicus izolatının tamamında 230 bp'lik bantlar gözlendi. Streptococcus equi etkenlerinin tür düzeyinde identifikasyonu için yapılan, pyrogenic exotoxin L (seel) gen bölgesinin amplifikasyonu sonucunda 520 bp'lik bant görüldü. Elde edilen 22 izolatın hepsi moleküler olarak tür düzeyinde doğrulandı. Antibiyogram testi sonucunda izolatların trimetoprim-sulfametoxazol, enrofloxacin, teicoplanin, imipenem'e duyarlı oldukları, clindamycin, neomycin, vancomycin, gentamicin, cefoxitin, penicilin G, kanamycin, streptomycin antibiyotiklerine ise farklı oranlarda duyarlılık saptandı. Sonuç olarak, S. zooepidemicus'un hastalığın etiyolojisinde rol oynayabileceği ve bu nedenle etkenin göz ardı edilmemesi gerektiği, S. zooepidemicus ve $S$. equi'nin identifikasyonunda PCR testinin yararlı olduğu görüldü. Antibiyogram testi sonucunda, özellikle aminoglikozidlere karşı bir direncin bulunduğu tespit edildi.
\end{abstract}

Anahtar Kelimeler: PZR, S. equi, Su sakağısı.

\section{The Molecular Identification and Antibiotic Sensitivity of Streptococcus equi Strains Isolated from Horses}

Abstract: Strangles is a contagious and acute disease in horses characterized by suppurative lymphadentis and caused by Streplococcus equi subsp. equi. The disease is usually seen in young foals. Abscessation in lymph nodes of the upper respiratory system is seen and rarely it is in generalized abscessation form. Strangles affect equines of all ages. In this study, it was aimed to isolate S.equi from horses and perform a molecular identification of the agent by PCR. It was also aimed to determine antibiotic sensitivity profiles of the isolates. For this purpose, tracheal washings and nasal swabs were collected from 60 horses. At the end of cultural studies, a total of 22 (36\%) Streptococci isolation were made. Out of 22 isolated strains tested, $3(19.1 \%)$ and 19 (20.6\%) were identified as S.equi and S. zooepidemicus, respectively. All isolates were verified by PCR. Amplification of SodA gen region of isolated strains yielded 230 bp DNA bands in agarose electrophoresis in both 3 S.equi and 19 S.zooepidemicus isolates. For species level molecular identification, amplification of Seel gen region was made by using specific primers and $520 \mathrm{bp}$ DNA bands were observed in gels under UV light. According to the antibiotic sensitivity test results, all isolates were sensitive to trimetoprim-sulfametoxazol, enrofloxacin, teicoplanin, imipenem; sensitivity to clindamycin, neomycin, vancomycin, gentamicin, cefoxitin, penicilin G, kanamycin, streptomycin was found relatively lower. At the end of the study, it was concluded that $S$. zooepidemicus could play a role in the disease besides S.equi. Therefore, this should be taken for consideration. It was also noted that PCR for molecular identification for S.equi and S.zooepidemicus might be a useful tool. Antibiotic sensitivity tests showed that there is a resistance to especially aminoglycosides.

Keywords: PCR, S.equi, Strangles.

\section{Giriş}

Atlarda performans düşüklüğüne neden olan hastalıkların başında solunum sistemi hastalıkları gelir. Safkan Arap ve İngiliz atı yetiştiricilerinin de karşılaştığı önemli sorunlardan birisi üst solunum yolları hastalıklarıdır. Su sakağısı, atlarda $S$. equi'nin neden olduğu akut seyirli, bulaşıcı ve irinli lenfadenitisle karakterize bir hastalıktır (Art ve ark., 2012). Hastalık genellikle genç taylarda görülür ve hastalıkta üst solunum yolu ile ilgili bölgesel lenf nodüllerinde veya ender olarak da generalize 
formda apseleşme görülür. Hastalık tüm yaşlardaki tek tırnaklıları etkiler. Klinik bulgular genç hayvanlarda belirgindir. Kalabalık, yetersiz havalandırma, barınak problemleri, yer değiştirme ve yarış gibi stres yaratan faktörler hastalığa predispozisyon yaratmaktadır (Arias, 2013).

Hastalığın teşhisinde, klinik bulgular önemli olmasına karşın laboratuvar sonuçları ile birlikte değerlendirilmesi hem teşhis hızı hem de ekonomik açıdan at popülasyonu ve yetiştiriciler için önem arz etmektedir. Su sakağısının klasik laboratuvar tanısında kültür yöntemi altın standart olarak bildirilmiştir (Sellon ve Long, 2013). Ancak diğer grup $\beta$-hemolitik streptokoklar ile $S$. equi kültür yoluyla ayrımı zor olduğundan dolayı PCR temelli tanı yöntemleriyle $S$. equi hızlı ve kolay bir şekilde identifiye edilebilmektedir. Antifagositik-M proteinin (SeM) PCR ile $S$. equi suşları identifıye edilebildiği bildirilmiştir (Chanter, 1997). Günümüzde, farklı bakteriyel hastalıklara karşı korunmada kemoterapotik ajanların kullanımı sıklıkla başvurulan yöntemlerdir. Yanlış ilaçların kullanımı antibakteriyel direnç kazanımı sonucunu da beraberinde getirmektedir. Antibiyotik duyarlılık testiyle uygun antibiyotik kullanımı sağlanarak hastalığın kısa sürede uygun bir şekilde tedavi edilmesi sağlanabilmektedir (Sweeney ve ark., 2004).

Atlarda solunum poblemleri at yetiştiriciliğinin en önemli problemi olarak karşımıza çıkmaktadır. $\mathrm{Bu}$ çalışma da atlardan kültür yoluyla $S$. equi izolasyonu ve bu izolatların PCR ile moleküler olarak identifikasyonu ve antibiyotik duyarlılık profillerinin saptanması amaçlandı.

\section{Materyal ve Metot}

$\mathrm{Bu}$ çalışmanın etik kurul raporu, Dollvet A.Ş Hayvan Deneyleri Yerel Etik Kurulu'ndan (Yetki numarası: DOLLVET-HADYEK-2016/29) alınmıştır.

$\mathrm{Bu}$ tez çalışmasında, 32 burun sıvabı ve 28 trakeal aspirasyon sıvısı olmak üzere toplam 60 örnek $S$. equi ve $S$. zooepidemicus yönünden incelendi. Steril olarak alınan örnekler soğuk zincirde en kısa sürede laboratuvara ulaştırılarak incelendi.

Bu çalışmada, örnekler 28 Ingiliz ve 32 Arap atından alındı. Bu hayvanların 30 (\%50)'u dişi 30 $(\% 50)^{\prime} u$ ise erkek idi. Örnek alınan atların $26^{\prime}$ sı (\%43,3) 1-3 yaş, 19'u (\%31,6) 4-6 yaş, 15’i (\%25)ise 7 yaşından büyük olduğu kaydedildi.

Kültür: Trakeal aspirasyon sıvısı 600 g'de 10 dakika santrifüj edildikten sonra besi yerlerine ekimleri gerçekleştirildi. Burun svapları ve santrifüjden sonra elde edilen peletler kolistin ve nalidiksit asit içeren kanlı agara (Columbia Agar
Base, Oxoid CM331) ekimler yapıldı ve $\% 5 \mathrm{CO}_{2}$ ortamda $37{ }^{\circ} \mathrm{C}$ inkubasyona bırakıldı. 24-48 saatlik inkubasyon sonunda tipik $\beta$ - hemolitik streptokok benzeri kolonilerin alt kültürleri yapıldı. Şüpheli kolonilerin koloni morfolojileri, gram boyama, katalaz ve karbonhidrat fermentasyon testleri gibi biyokimyasal testlerle yapılarak identifikasyonları standart yöntemlere göre yapıldı (Quinn ve ark., 2004).

Moleküler Teknikler: DNA ekstraksiyonu:Alber ve ark. (2004)'nın bildirdiği yönteme göre yapıldı. Kısaca $1 \mu \mathrm{l}$ mutanolysin $(5 \mathrm{U} / \mu \mathrm{l})$ içeren TE buffer (10 $\mathrm{mmol} / \mathrm{l}$ Tris-HCL, $1 \mathrm{mmol} / \mathrm{l}$ EDTA, $\mathrm{pH}$ 8) içerisinde koloniler süspanse edildi ve $37^{\circ} \mathrm{C}^{\prime}$ lik su banyosunda 60 dakika bekletildi. Daha sonra süspansiyon 56 ${ }^{\circ} \mathrm{C}$ 'de 120 dakika proteinaz $\mathrm{K}$ ile muamele edildi. Süspansiyon $100{ }^{\circ} \mathrm{C}$ 'de 15 dakika kaynatıldıktan sonra üst kısım alınarak amplifikasyonda kullanılıncaya kadar $20^{\circ} \mathrm{C}^{\prime}$ de saklandı.

PZR: Aynı reaksiyon karışımı ve aynı şartlarda SodA ve Seel primerleri kullanılarak iki ayrı PZR yapıldı (Tablo 1).

\begin{tabular}{|c|c|c|}
\hline $\begin{array}{l}\text { Hedef } \\
\text { gen }\end{array}$ & Sekans $\left(5^{\prime}-3^{\prime}\right)$ & $\begin{array}{l}\text { PCR ürün } \\
\text { büyüklüğü } \\
\text { (bp) }\end{array}$ \\
\hline Seel & $\begin{array}{l}\text { seel F 5'GAA GGT CCG CCA TाT TCA GGT AGT TாG 3', } \\
\text { seel R 5'GCA TAC TCT CTC TGT CAC CAT GTC CTG 3'. }\end{array}$ & 520 \\
\hline SodA & $\begin{array}{l}\text { sodA equi/zooep F5'CAG CAT TCC TGC TGA CAT TCG TCA GG 3'. } \\
\text { sodA equi/zooep R5' CTG ACC AGC CTT ATT CAC AAC CAG CC } 3^{\prime} \text {. }\end{array}$ & 230 \\
\hline
\end{tabular}

PZR reaksiyon karışımı; $2 \mu$ template DNA, 0.4 $\mu \mathrm{l}$ dNTP karışımı, $0.7 \mu \mathrm{l}$ primerler (seel F,seel R), $2 \mu \mathrm{l}$ reaksiyon buffer, $0.2 \mu \mathrm{l}$ Taq DNA polimeraz ve son hacmi $20 \mu$ l olacak şekilde steril distile sudan oluştu. PCR inkübasyon sıcaklık ve süreleri sırasıyla, 95 ${ }^{\circ} \mathrm{C}$ 'de 15 dakikalık ilk denatürasyon, takiben $94{ }^{\circ} \mathrm{C}$ 'de 30 saniyelik denatürasyon, $59{ }^{\circ} \mathrm{C}^{\prime}$ de 30 saniye primer bağlanması, $72{ }^{\circ} \mathrm{C}^{\prime}$ de 40 saniye ekstensiyonu içeren 30 siklus ve $72{ }^{\circ} \mathrm{C}^{\prime}$ de 5 dakikalık final ekstensiyonundan oluştu (Alber ve ark., 2004).

PZR Ürünlerinin Görüntülenmesi: PZR sonucunda amplifıye edilen ürünler, TAE buffer kullanılarak \%1'lik agaroz jel'de elektroforeze tabi tutuldu. Sonuçlar UV transilluminatörde değerlendirildi.

Antimikrobiyal Duyarlılık Testi: $S$. equi ve $S$. zooepidemicus olarak identifiye edilen bakterilerin antibiyotik duyarlılıkları "National Committee for Clinical Laboratory Standards (CLSI)" (M2-A6) önerilerine uygun olarak disk difüzyon yöntemi ile belirlendi. Bu amaçla TSB (Tryptone Soya Broth, CM0129, Oxoid) bulunan tüplere ekimler gerçekleştirilerek $37^{\circ} \mathrm{C}^{\prime}$ de 24 saat inkübe edildi. İnkübasyon sonucunda $0.5 \mathrm{Mc}$ Farland yoğunluğuna göre getirilen kültürler Mueller Hinton Agar (CM0337, Oxoid) petrilerine svap yardımıyla 
ekimleri gerçekleştirilerek kurumaya bırakıldı. Standart antibiyotik diskleri pens yardımı ile eşit aralıklarla petriye yerleştirildi. Petriler $37^{\circ} \mathrm{C}^{\prime}$ de 18 saat inkübasyona kaldırıldı. İnkübasyon sonrasında inhibisyon zon çapları ölçüldü ve standart zon çapları "Clinical and Laboratory Standards Institute (CLSI)" karşılaştırıldı ve sonuca göre "duyarlı" veya "dirençli" olmak üzere değerlendirildi (Patel ve ark., 2015).

Bu amaçla enrofloxacin (10 ug), imipenem (10 ug), clindamycin (2 ug), neomycin (10 ug), teicoplanin (30 ug), vancomycin (30 ug), gentamicin (10 ug), cefoxitin (30 ug), penicilin G (10 U), kanamycin (30 ug), streptomycin (10 ug) kullanıldı.

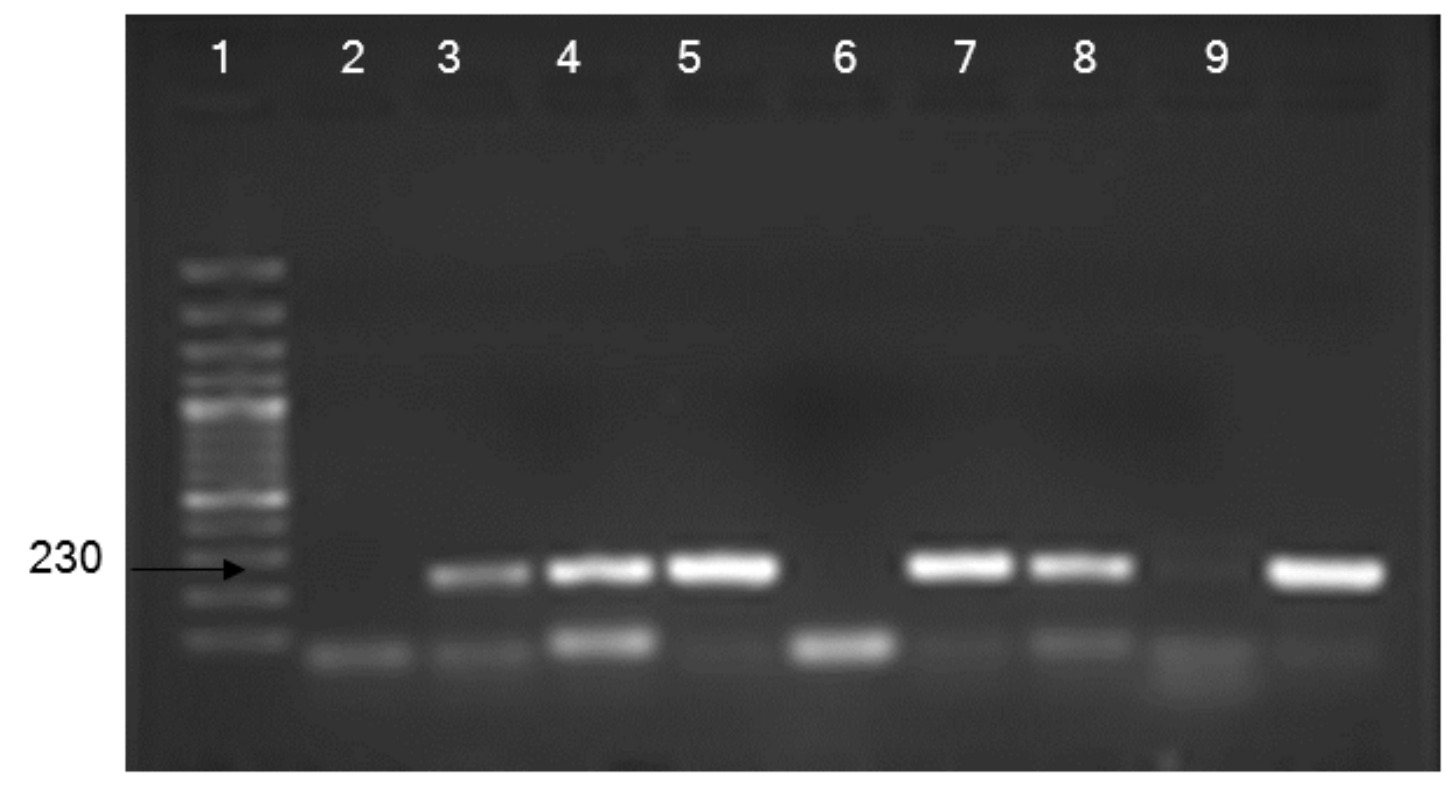

Şekil 1. S. equi ve S. zooepidemicus sod A spesifik PZR ürünü. M: Moleküler ağırlık marker (Gene Ruler 100 bp DNA Ladder Plus, Fermentas, Litvanya) 1-Negatif kontrol (S.pyogenes), 2,3,4- S. equi pozitif suşlar. 6,7.9. S. zooepidemicus, 5, 8, Negatif örnekler.

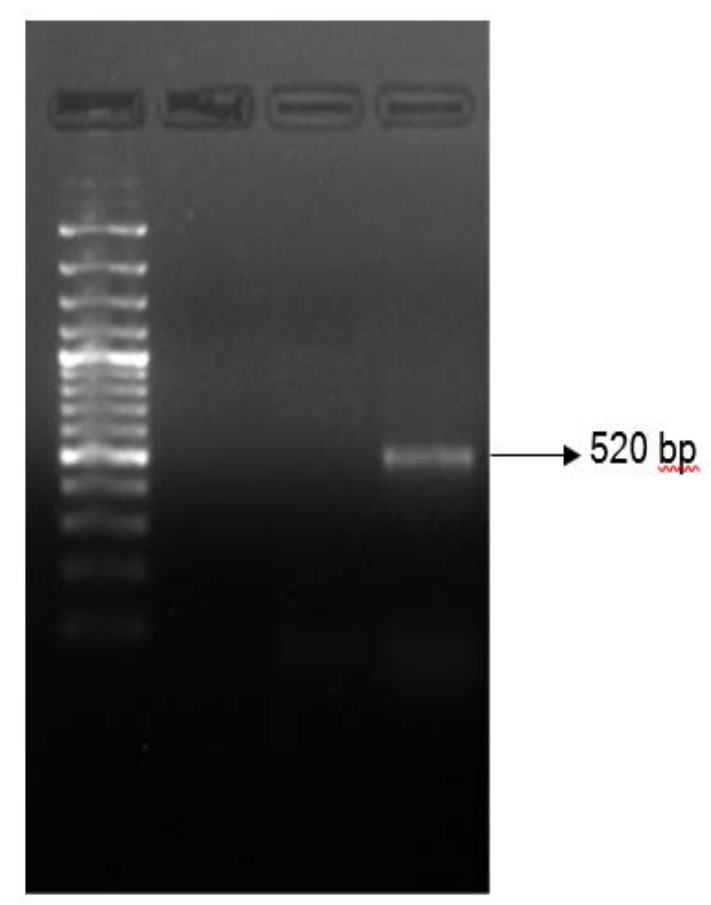

Şekil 2. Streptococcus equi spesifik PCR ürünü. M: Moleküler ağırlık marker (Gene Ruler 100 bp DNA Ladder Plus, Fermentas, Litvanya). 1-2 negatif örnekler 3. Pozitif örnek

\section{Bulgular}

İzolasyon ve İdentifikasyon Bulguları: $\mathrm{Bu}$ çalışma da incelenen 60 örneğin 22'sinden (\%36) streptokok izolasyonu gerçekleştirildi. Elde edilen 22 izolatın, 3'ü (\%19) S. equi, 19'u $(\% 20,6)$ S. zooepidemicus olarak identifîye edildi.

PZR Bulguları: SodA gen bölgesinin amplifıkasyonu sonucunda 3 adet $S$. equi ve 19 adet $S$. zooepidemicus suşlarının tamamında 230 bp'lik bantlar gözlendi (Şekil 1).

Streptococcus equi etkenlerinin tür düzeyinde identifıkasyonu için yapılan, Seel gen bölgesinin amplifikasyonu sonucunda 520 bp'lik bant görüldü (Şekil 2). Sonuç olarak, konvansiyonel tekniklerle Streptococcus spp. olarak identifiye edilen 22 adet suşun tamamı moleküler olarak olarak doğrulandı.

İzole edilen etkenlerin antibiyogram sonuçları Tablo 2'de gösterilmiştir. Antibiyogram sonucunda trimetoprim-sulfametoxazol, enrofloxacin, teicoplanin, imipeneme bütün suşlar duyarlı bulundu. Clindamycin, neomycin, vancomycin, gentamicin, cefoxitin, penicilin G, kanamycin, streptomycin antibiyotiklerine ise daha az oranda duyarlılık saptandı. 
Tablo 2. İzole edilen etkenlerin antibiyogram testi sonuçları.

\begin{tabular}{lll}
\hline Antibiyotikler & $\begin{array}{l}\text { S. zooepidemicus } \\
\text { Dirençli/Duyarlı (\% Duyarı) }\end{array}$ & $\begin{array}{l}\text { S. equi } \\
\text { Dirençli/Duyarlı (\% Duyarı) }\end{array}$ \\
\hline & (n:19) & (n:3) \\
\hline $\begin{array}{l}\text { Penisilin G (10 ug) } \\
\text { Trimetoprim- }\end{array}$ & $1 / 18(\% 94,7)$ & $0 / 3(\% 100)$ \\
Sülfametoksazol (25 ug) & $0 / 19(\% 100)$ & \\
Enrofloxcacin (10 ug) & $0 / 19(\% 100)$ & $0 / 3(\% 100)$ \\
Kanamisin (30 ug) & $2 / 17(\% 89,4)$ & $0 / 3(\% 100)$ \\
Gentamisin (10 ug) & $3 / 16(\% 84,2)$ & $2 / 1(\% 33,3)$ \\
Streptomisin (10 ug) & $4 / 15(\% 78,9)$ & $1 / 2(\% 66,6)$ \\
Neomisin (30 ug) & $4 / 15(\% 78,9)$ & $2 / 1(\% 33,3)$ \\
Vancomycin (30 ug) & $0 / 19(\% 100)$ & $2 / 1(\% 33,3)$ \\
Teicoplanin (30 ug) & $0 / 19(\% 100)$ & $1 / 2(\% 66,6)$ \\
Cefoxitin (30 ug) & $2 / 17(\% 89,4)$ & $0 / 3(\% 100)$ \\
Imipenem (10 ug)) & $0 / 19(\% 100)$ & $0 / 3(\% 100)$ \\
Clindamycin (2 ug) & $1 / 18(\% 94,7)$ & $0 / 3(\% 100)$ \\
\hline
\end{tabular}

\section{Tartışma ve Sonuç}

Su sakağısı, çok fazla bulaşma özelliğine sahip S. equi tarafından oluşturulan, genellikle taylarda üst solunum yollarında ve bölgesel lenf yumrularının iltihaplanması ile karakterize, akut seyirli bir enfeksiyondur. Stres, bakımsızlık, iklim değişiklikleri gibi faktörler hazırlayıc faktörlerdir. Hastalık burun akıntıları ve etkilenen lenf yumrularında bulunan irin ile kolayca saçılabilmektedir. Hastalık at endüstrisinde oldukça önemli ekonomik kayıplara neden olmaktadır (Piche, 1984).

Streptococcus zooepidemicus çoğunlukla atların üst solunum sisteminde kommensal olarak bulunan $S$. equi ile yakın akrabalığı olan bir mikroorganizma olarak kabul edilmektedir. $S$. zooepidemicus kısraklarda metritis ve atlarda kornea ülseri gibi çeşitli hastalıklar ile ilişkili olduğu bildirilmiştir. Ayrıca atların bademciklerine yerleşen S. zooepidemicus suşlarının, patojenik suşları kapsadığı da belirtilmiştir. S. zooepidemicus solunum sisteminde ciddi hastalıklara neden olan fırsatçı bir bakteridir. Ayrıca mukoza da kommensal olarak bulunmakla beraber su sakağısı benzeri semptomlar gösteren atlardan da izole edilmiştir (Erol ve ark., 2012).

Erol ve ark. (2012), atlarda hemolitik streptokok türlerini araştırdıkları bir çalışmada, $S$. zooepidemicus'un en sık izole edilen tür olduğunu bildirmişlerdir. Araştırıcılar, plasenta, fötal doku, solunum sistemi, nasal örnekleri ve lenf düğümü apseleri gibi çeşitli organlardan $\% 72$ oranında izolasyon bildirmişlerdir. Araştırıcılar etkeni temel olarak lenf düğümü apsesi, nasal svaplar, üst ve alt solunum kanalından izole etmişlerdir. Ayrıca aynı araştırmada, \%5,8 gibi düşük bir oranda fötal doku ve plasentadan S. equi suşları izole edilmiştir (Erol E ve ark., 2012).

Khoo ve ark. (2011), 2010 yıllında 2825 burun,
9 trakeal, 1 submandibular svab ve 1 submandibular apseden aldıkları örnekleri kültür yoluyla inceledikleri çalışmada, 2 burun svabı ve 1 submandibular apseden $S$. equi izole etmişlerdir. Çalışmada 2847 örnekten $3 \quad(\% 0,1)$ izolasyon oranının çok düşük olduğunu belirtmişlerdir. Yeni Zelanda'da S. equi'nin PZR ile identifikasyonunun amaçlandığı bir çalışmada 168 attan örnekler alınmıştır (Patty ve Cursons, 2014). Bu örneklerin PZR ile incelenmesi sonucunda $35(\% 20,8)$ attan PZR ile pozitiflik saptanmıştır. Araştırıcılar (Patty ve Cursons, 2014), PZR'testinin hastalığın teşhisinde hızlı ve duyarlı bir yöntem olduğunu bildirmiştir. Jannatabadi ve ark. (2008), 30 attın üst solunum yollarından burun svabı aldıkları çalışmada $1(\% 0,3)$ adet $S$. equi ve 24 (\%80) adet S. zooepidemicus izole ettiklerini bildirmişlerdir.

Mir ve ark. (2013), Hindistan'da 88 baş sağlıklı ve 53 baş solunum yolu hastalığı bulunan atlarda, üst solunum yollarında aerobik bakterileri izole ettikleri çalışmada, her iki gruptan izole edilen toplam 321 izolattan $\% 84,11^{\prime} i$ gram pozitif ve $\% 15,88^{\prime} i$ gram negatif bakteri olarak tespit etmişlerdir. Araştırıcılar, \%7,44 oranında Streptococcus equi subsp. zooepidemicus ve $\% 1,24$ oranında Streptococcus equi subsp. equi izole ettiklerini belirtmişlerdir. Türkiye'de yapılan bir çalışmada (Diri M, 2018), 133 numuneden 2 Streptococcus spp. $(\% 1,2)$ (1 Streptococcus equi subs. zooepidemicus ve 1 Streptococcus pneumonia) etkeni izole edilmiştir. Çalışmada doğal florada bulunan Gram negatif bakterilerin baskılayıcı etkisinden dolayı bakteri oranının düşük çıktığı belirtilmiştir.

Bu çalışmada, 60 su sakağısı şüpheli attan alınan örneklerden, $3(\% 0,5)$ adet $S$. equi ve 19 $(\% 31,6)$ adet $S$. zooepidemicus izole ve identifiye edildi. S. zooepidemicus'un daha yüksek ve $S$. equi izolasyon oranındaki düşüklük, diğer çalışmalardan 
elde edilen izolasyon oranlarına benzer bulunmuştur (Diri M, 2018). Farklı bölgeler de yapılan çalışmalarda izolasyon oranları değişebilmektedir. Antibiyotik kullanılması, florada diğer bakteriyel etkenlerin varlığı izolasyon oranlarını etkileyebilmektedir.

S. equi'nin klasik identifikasyonu fenotipik özellikleri, morfoloji, serolojik ve biyokimyasal özelliklerine bağlıdır. Ancak klasik izolasyon için uzun zaman gereklidir ve atipik suşlar gözden kaçabilmektedir. Bu nedenle araştırıcılar tarafından hızı spesifik ve duyarlı moleküler tanı yöntemlerinden klasik PZR metodları geliştirilmiştir (Alber ve ark., 2010; Patty ve Cursons, 2014).

Alber ve ark. (2010), S. equi'ye spesifik Seel ve hem S. equi hemde S. zooepidemicus'a spesifik SodA genlerini temel alan PZR geliştirdikleri çalışmada her iki türü başarılı bir şekilde ayırt ettiklerini bildirmişlerdir. Çalışmamızda izole edilen bütün suşlar PZR testi ile doğrulanmıştır. PZR testinin, izole edilen her iki türün ayırımında başarılı bir şekilde kullanıldığı görülmüştür.

Kuzey Amerika'da, 755 S. zooepidemicus'un izolatının ceftiofur ve 6 antibiyotiğe karşı invitro aktivitesi incelenmiş. Ceftiofura, S. zooepidemicus izolatlarının \%90'nının duyarlı olduğu bildirilmiştir (Bade ve ark., 2009). Bu çalışmada cefoxitine duyarlılığın \%89,4 olarak bulunması Bade ve ark. (2009)'nın bulgularına benzer olarak görülmüştür. Johns ve ark. (2012), Atlardan alınan klinik örneklerden izole edilen bakterilerin, antimikrobiyal direnç değişimlerini inceledikleri bir çalışmada enrofloxacin, ceftiofur, gentamicin, penicillin G, trimethoprim-sulfamethoxazole and tetracycline duyarlılıklarını incelemişlerdir. İzolatları iki gruba ayırmışlardır. Illk grupta 1999-2004 yılları arasında izole edilenler, diğer grupta ise 2007-2012 yılları arasında izole edilen bakterilerden oluşmuştur. Streptokok türlerinde direnç oranında önemli artışlar olduğunu belirlemişlerdir. Bütün Streptokok türlerinin ilk grupta enrofloksasine direncin sıfır olarak görülmesine karşın ikinci grupta bu oranın \%63 seviyelerine çıktığını bildirmişlerdir. Ayrıca tetrasiklin ve çoklu antibiyotik direncinin $S$. zooepidemicus suşlarında artığını ve trimethoprimsulfamethoxazole direncinin ise azaldığını belirtmişlerdir. Antibiyotik direncinin artmasının yaygın ilaç kullanımına bağlamışlardır.

Sauer ve ark. (2003), atların ülseratif keratitis olgularından 65 izolatın 13'ünü (\%20) S. zooepidemicus olarak identifiye etmişlerdir. Bu izolatların 1993 -1997 yılları arasında 1/5'inin (\%20) gentamisine dirençli iken 1998- 2000 yılları arasında $4 / 8$ 'sinin (\%50) gentamisine dirençli olduğunu bildirmişlerdir. Bu direnç oranının istatistiksel olarak önemli olduğunu belirtmişlerdir. Diğer antibiyotiklerde bir değişim görmedikleri çalışmada 13 izolatın tamamını bacitracin, ampicillin, chloramphenicol ve carbenicilline duyarlı bulmalarına karşın, neomycin ve kanamycine karşı direnç şekillendiğini belirtmişlerdir. Başka bir çalışmada Luque ve ark. (2006), endometritis klinik belirtileri olan kısraklardan izole edilen $65 \mathrm{~S}$. zooepidemicus'un $\quad \beta$-lactam, enrofloksasin, trimetoprim-sulfamethaksazole ve gentamisine duyarlı olduğunu bildirilmiştir. Araştırıcılar aminoglikozid duyarlılığının değişken olduğunu, amikasine ve karşı yüksek oranda $(\% 98,5)$ direnç tespit ederken, gentamisin duyarlılığını yüksek $(\% 98,5)$ olarak bildirmişlerdir. Erol ve ark. (2012), $2497 \beta$ - hemolytic streptokok etkenin direnç profillerini inceledikleri çalışmada, genel olarak suşların, cephalothin, erythromycin, nitrofurantoin, penicillin, ticarcillin ve clavulanate duyarlı olduğu, gentamicin, tetracycline, novobiocin,ve bacitracine daha az duyarlı olduğunu bildirmişlerdir.

Hastalığın tedavisinde tercih edilen ilaçlar olarak penicillin, sefalosporin ve makrolidler karşımıza çıkmaktadır. CLSı standarlarına göre yapılan antibiyogram test sonuçları temel alındığında $S$. equi izolatların büyük çoğunluğunun trimetoprime-sulfadiazine duyarlı olduğu görülmüştür. Diğer birçok antibiyotiğe karşı direncin düşük olduğu görülmütür. Strepkokok etkenlerine karşı gentamisini içeren aminoglikozid direnci gözlenebilmektedir. Antibiyotik direnç gelişimi antibiyotik kullanımına bağlı olduğundan, yapılan çalışmalarda farklı sonuçlar alınabilmektedir. Bizim çalışmamızda elde ettiğimiz antibiyotik direnç sonuçları diğer çalışmalarla karşılaştırıldığında, özellikle aminoglikozidlere karşı direnç bulunması, diğer araştırıcıların bulgularına benzer olarak görülmüştür.

Çalışmada, incelenen örneklerin 22'sinden (\%36) Streptokok izolasyonu gerçekleştirildi. İzole edilen suşlardan $3(\% 0,5)$ adeti S. equi ve $19(\% 31,6)$ adeti S. zooepidemicus olarak belirlendi. Bu sonuç, genel olarak $S$. zooepidemicus'un hastalığın etiyolojisinde rol oynayabileceğini ve bu nedenle etkenin göz ardı edilmemesi gerektiğini, $S$. zooepidemicus ve $S$. equi'nin identifikasyonunda PZR testinin yararlı olduğunu ve türlerin ayrılmasında oldukça etkin bir şekilde kullanılabileceğini ve izole edilen etkenlerin genel olarak antibiyotiklere duyarlı olduğu, ancak aminoglikozidlere karşı direncin oluştuğunu gösterdi. Bu çalışmada elde edilen bulgular çerçevesinde, su sakağısının etiyolojisinin belirlenmesine ve kontrol programlarının düzenlenmesi ile de streptokok ve diğer etkenlere bağlı enfeksiyonların çözümüne önemli katkılar sağlayacaktır. 


\section{Teşekkür}

Bu çalışma, Harran Üniversitesi Bilimsel Araştırma Projeleri Koordinatörlüğü tarafından, 17056 proje numarası ile desteklenmiştir.

\section{Kaynaklar}

Art T, Mc Gorum B, Lekeux P, 2012: Environmental Control of Respiratory Disease. IVIS, Ithaca, New York, USA.

Arias MP, 2013: Strangles: The most prevalent infectious respiratory disease in horses worldwide. Rev CES Med Zootec, Vol 8 (I), 143-159.

Alber J, El-Sayed A, Lämmler C, Hassan AA, Weiss R, Zschöck M, 2004: Multiplex polymerase chain reaction for identification and differentiation of Streptococcus equi subsp. zooepidemicus and Streptococcus equi subsp. equi. $J$ Vet Med $B$ Infect Dis Vet Public Health, 51(10), 455-458.

Bade DJ, Sibert G, Hallberg J, Portis E, Boucher J, Bryson W, 2009: Ceftiofur susceptibility of Streptococcus equi subsp zooepidemicus isolated from horses in North America between 1989 and 2008. Vet Ther, 10(4), E1-7.

Chanter N, 1997: Streptococci and enterococci as animal pathogens. In: Symposium Series-Society for Applied Bacteriology (United Kingdom). Suppl, 83, 10051095.

Diri M, 2018: Türkiye'deki yarış atlarının solunum yollarından izole edilen Streptococcus spp ve Staphylococcus spp etkenlerinde antibakteriyel ilaçlara direncin tespit edilmesi. Doktora Tezi, Ankara Sağlık Bilimleri Enstitüsü, Ankara.

Erol E, Locke SJ, Donahoe JK, Mackin MA, Carter CN, 2012: Beta-hemolytic Streptococcus spp. from horses: a retrospective study (2000-2010). J Vet Diagn Investig, 24 (1), 142-147.

Johns IC, Adams EL, 2015: Trends in antimicrobial resistance in equine bacterial isolates: 19992012. Vet Rec, 176 (13), 334-334.

Jannatabadi, AA, Mohammadi GR, Rad M, Maleki M, 2008: Molecular identification of Streptococcus equi subsp. equi and Streptococcus equi subsp. zooepidemicus in nasal swabs samples from horses suffering respiratory infections in Iran. PJBS, 11 (3), 468-471.

Khoo LL, Maswati MA, Roseliza R, Rosnah Y, Saifu Nazri R and Ramlan M. 2011. Isolation of streptococcus equi during strangles surveillance in peninsular Malaysia. Malaysian Journal of Veterinary Research, 2, 27-32.

Luque I, Fernández-Garayzábal JF, Blume V, Maldonado A, Astorga R, Tarradas C, 2006: Molecular Typing and Anti-microbial Susceptibility of Clinical Isolates of Streptococcus equi ssp. zooepidemicus from Equine Bacterial Endometritis. J Vet Med B Infect Dis Vet Public Health, 53 (9), 451-454.

Mir IA, Kumar B, Taku A, Wani N, Faridi FN, Dar SA, Gazal S, Badroo GA, Zargar AA and Iqbal A, 2013: The study of aerobic bacterial flora of the upper respiratory tract of equines from Jammu and Kashmir region of India. Veterinary World, 6 (9), 623-627.

Patel JB, Cockreilli F, Bradford P, Eliopoulos G, Hindler J, Jenkins S, 2015: Performance Standards for Antimicrobial Susceptibility Testing: Twenty-Fifth Informational Supplement; M100-S25. Wayne, Pennsylvania: Clinical and Laboratory Standards Institute.

Patty OA, Cursons RTM, 2014: The molecular identification of Streptococcus equi subsp. equi strains isolated within New Zealand. NZVJ, 62 (2), 63-67.

Piche CA. 1984: Clinical observationsan outbreak of strangles. Can Vet J, 25:711.

Sauer P, Andrew SE, Lassaline M, Gelatt KN, Denis HM, 2003: Changes in antibiotic resistance in equine bacterial ulcerative keratitis (1991-2000): 65 horses. Vet Ophthalmol, 6 (4), 309-313.

Sellon DC, Long M. 2013: Equine Infectious Diseases EBook. Elsevier Health Sciences.

Sweeney CR, Timoney JF, Newton JR, Hines MT, 2005: Streptococcus equi infections in horses: guidelines for treatment, control, and prevention of strangles. J Vet Intern Med, 19 (1), 123-134.

Quinn PJ, Carter ME, Markey B, Carter GR, 2004: Clinical veterinary microbiology. Mosby. Elsevier, London.

*Yazışma Adresi: Osman Yaşar TEL

Harran Üniversitesi, Veteriner Fakültesi, Mikrobiyoloji Anabilim Dalı, Şanlıurfa, Türkiye.

e-mail:oyasar@gmail.com 